\title{
教育講演 平成18年5月21日
}

\section{高歯化社会を若々しく生きるためのアンチエイジング}

\section{サンクリニック 市橋 正光}

\section{高齢化国家日本}

高齢化国家に入った日本では, 活力ある社会作 りを若者だけに頼ることは不可能と思われる．約 10年後には75歳以上の後期高齢者の数が $65 〜 74$ 歳 の前期高齢者数を越えるといわれている（図1）.

図1 日本の高齢者の構成変化

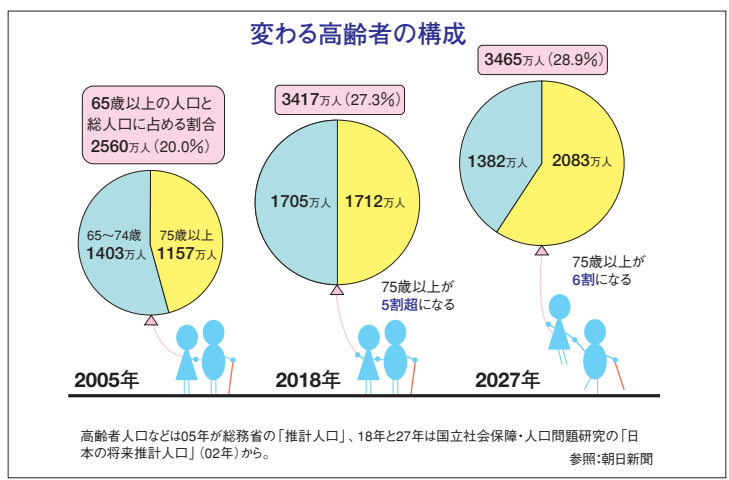

約20年後には65歳以上の高齢者が30\%近くに増加し, さらに75歳以上の 後期高齢者（75歳以上）が前期高齢者（65歳～74歳）をはるかに超える と予測されている.

従って，わが国が活力有る社会を維持するために は1人でも多くの高齢者が，社会で若者や子ども 達と共に生きていくことが望まれる。そのために は単なる平均寿命ではなく, 健康で自立した社会 人として生活できる健康寿命を延ばさなければな らない. そのため, 近年アンチエイジングの重要 性が認識されてきている。私ども一人一人がアン チエイジングの大切さ, 必要性を理解し, 実践し なければならない.アンチエイジングで可能とな る皮膚の若々しさは心と身体の両面から長寿社会 に欠かせないものである。

高齢化社会の日本では, 老人医療, 老人雇用, 老人福祉, 老人介護などの高齢者関連の諸問題解 決の一つの方法は, 健康な体と心を持った高齢者 が社会参加することである。そのために求められ
ているのがアンチエイジング医学である。アンチ エイジング医学の対象は高齢者だけではなく, 若 くてまだ加齢を自覚していない人も入る.理論的 には成長期の子どもの頃からアンチエイジングを 始めるべきである．特に，皮膚の若々しさは環境 因子の太陽紫外線に大きく左右される。尒どもの 頃から毎日浴びる紫外線が皮膚の若さを着実に奪 っていく．大人の顔は太陽が造ったといえる.

\section{老化と光老化}

線虫は約 1 ケ, マウスは 2 年, ヒトは 120 年とそ れぞれ寿命がある。この事実から想像できるが， 寿命を決定するのは遺伝子と考えられている．近 年, ヒトでは寿命が著しく短い早老症や光早老症 で単一遺伝子の変異が明らかになり, それらの責 任遺伝子が次々と同定され, 機能解析が進められ ている.

現在, 寿命の長さを左右する遺伝子として, 線 虫ではage-1 ${ }^{11}$, daf- $2^{2}$, daf-16, 出芽酵母ではsir-2 (silencing information regulator-2) が脚光を浴び ている。また，マウスではklotho遺伝子を過剩発 現させると，産物klotho蛋白質はレセプターを介 して細胞内に情報伝達し，インスリンシグナル伝 達系による糖利用を抑制することが最近報告さ れ，長寿につながると考えられている。

ヒトでは短命の遺伝性疾患から, 寿命や老化に 関わる遺伝子群が同定されてきている．皮膚老化 も多くの遺伝子の制御下にあると考えられる。早 老症のウェルナー症候群の責任遺伝子 $W R N$ は DNAヘリケース活性を持っており, その変異が早 老症を引き起こす。その他, Hutchinson-Gilford ProgeriaのLMNA，ブルーム症候群のBLM， ロス ムンド・トムソン症候群のRTS, A t axia TelangiectasiaのATM, コケイン症候群のCSBは, 
いずれも早老症に関連した遺伝子である。これら の多くの遺伝子は，大腸菌の紫外線損傷に関わる 遺伝子RecQと相同性が高いDNAヘリケースであ る. DNAヘリケースはゲノム維持機構の一翼を担 っているが，ヘリカケース活性に異常が起きると， DNA修復や複製の異常, 染色体の不安定性により 早老症を引き起こすと考えられる．2002年，Bohr らはXPD群遺伝子に変異を持つTTD症候群のマウ スを作成し，寿命が著しく短いことを示した。さ らにXPA群遺伝子をノックアウトした 2 重遺伝子 欠損マウスでは，老化はさらに早期に起こり，活 性酸素のストレスにも著しく過敏なことを示し， 遺伝子が寿命に大きく関わることを証明してい る。

皮膚の老化とは，皮膚を構成している個々の細 胞の機能低下であり，表皮，真皮やその結合部， 附属器の機能低下に加え, 形態に異常が生じるこ とと定義できる，通常20歳頃までは，皮膚の老化 症状であるシミ・シワや腫瘍は発症しない。また， 60歳を過ぎると好発する冬季の皮膚の乾燥および 痒みなども若いときには発症しない。さらに，顔 や手背皮膚は小児期から常に太陽紫外線にさらさ れているために, 光老化と呼ばれる症状を呈する. 本稿では光老化に重点を置き, その発症メカニズ ムとそのアンチエイジング法を概説する.

\section{活性酸素と皮膚老化・光老化}

太陽紫外線を浴びると, 皮膚では速やかに ${ }^{1} \mathrm{O}_{2} や$ $\mathrm{O}_{2}$-が生成される。さらにサンバーン（炎症）では 浸潤細胞により皮膚組織で活性酸素が生成される ため, 太陽紫外線を浴びた皮膚は他の臓器に比べ, 多量の活性酸素に曝される。活性酸素が細胞内外 の消去能力を超えて生成されると酸化ストレスと なり，蛋白質，脂質，糖および核酸が酸化される。 酸化DNAは正しく修復されれば問題はないが，D $\mathrm{NA}$ 複製時に8-OHdGが残っていると細胞分裂後 に $\mathrm{G} \rightarrow \mathrm{T}$ 変異が生じる可能性があり遺伝子異常（突 然変異）となる. 最近Kunisadaらは, 酸化塩基の 修復に関与しているOGG1遺伝子をノックアウト したマウスで紫外線による皮膚がん発症の時期が 早いことを示し, 塩基酸化が紫外線発ガンに関与
していることを強く示唆した.

紫外線 $\mathrm{A}$ は表皮角化細胞内のメラニンモノマー DHICA 6 H5MICAを, $\mathrm{H}_{2} \mathrm{O}_{2}$ 存在下で効率よくポ リマー化し，皮膚を黒化させることが明らかにさ れている。この皮膚の黒化は従来考えられていた 即時黒化とは異なり, 数週間消失しない.

さらに, シミの発症にも活性酸素, 特に $\mathrm{O}_{2}$-が必 要と考えられており，また抗酸化剤が紫外線誘発 メラニン生成に関係するPOMC（プロオピオメラ ノコルチン，色素細胞のメラニン生成を刺激する ペプチド $a-\mathrm{MSH}$ 前駆物質）の生成を抑えるこ となどから活性酸素の生成を抑制し，消去能を高 めることはシミの発生抑制につながると考えられ る.

紫外線照射を受けた皮膚細胞ではコラゲナーゼ (MMP-1)，ゼラチナーゼとストロメライシンの mRMAのupregulationとタンパク量の増大により コラーゲンと弾性線維が切断されると考えられ る.

\section{光老化の発症メカニズム}

光老化症状は，長年にわたり，繰り返し日光曝 露を受けた顔や手背の皮膚にみられ，一般の加齢 による老化症状とは質的に異なっている．20歳を 過ぎるころから顔，手背や上背部皮膚には光老化 症状として小色素斑（老人性黒子）が出始め，40 歳を過ぎると良性腫瘍（脂漏性角化症）が次々と 発生する. 同時に顔面にはしわも目立ってくる. さらに男性では60歳，女性では70歳を過ぎると前 癌症の日光角化症が好発する。

筆者らは，緯度が北緯39.43度の秋田市と 31.36 度 の鹿児島市の女性（6～80歳）それぞれ350人を対 象に, 顔面皮膚の特定部位の色素班の面積と, し わ（深さ $0.5 \mathrm{~mm}$ 以上，長さ $0.5 \mathrm{~mm}$ 以上）を計測す るため, CCDカメラで撮影しコンピューターに取 り込ませ，一定面積あたりのシミの面積としわの 数を両地域で比較した。なお，鹿児島は秋田に比 べ，年間紫外線B（UVB）量は約1.6倍である。鹿 児島の女性では，20歳を過ぎるとシミが急速に増 え始め, 40歳ころには秋田の女性の60歳と同程度 のシミができる。つまり20歳も早く光老化症状が 
図2 年間紫外線量がシミの発症に与える影響

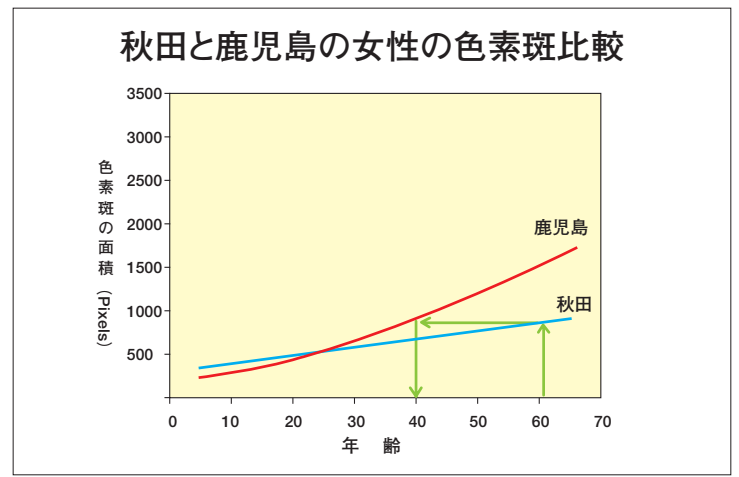

年間太陽紫外線量が秋田の約1.6倍の鹿児島の女性は, 秋田の女性に比べ 20歳も早くシミが増加している.

進むことが明らかになった（図2）。

\section{（1）紫外線による遺伝子損傷と修復エラーによる 変異と光老化}

紫外線や活性酸素は主に表皮角化細胞の遺伝子 に傷をつける。太陽紫外線のうちでも特に紫外線 B（ultraviolet B：UVB）は，遺伝情報を含む DNAにシクロブタン型ピリミジン二量体 (cyclobutane pyrimidine dimer ; CPD) や(6-4) 光産物（6-4 photoproduct）などの独特の傷をつ ける（図4）。真夏の快晴日の正午に 1 時間太陽紫 外線を浴びると, 表皮上層では 1 個の細胞の全ゲ ノムあたり約 100 万個, 表皮最内層にあり分裂す る基底層細胞でも 5 10万個もの傷ができる.太 陽紫外線の $90 \%$ 以上を占める紫外線A（ultraviolet A：UVA）は塩基の酸化損傷以外にも，Bの約

図3表皮メラニンはDNA損傷を軽減する

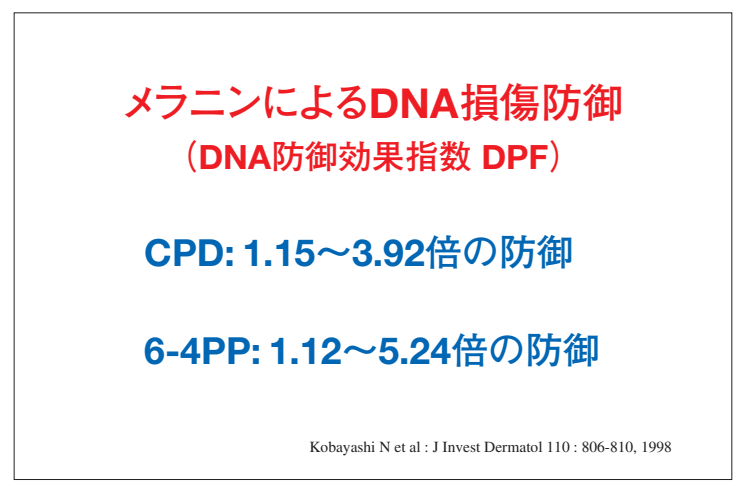

サンタンが生じた皮膚では, シクロブタン2量体（CPD）と（6-4）光生 成物の生成を約3〜 5倍軽減する.
1000倍量の大量照射でCPDを生成し，Bと同様に C-T,CC-TT変異を遺伝子に誘発する。

細胞は D N A 損傷に対処するため，除去修復機 構には，転写共䡉修復と全ゲノム修復の 2 系が存 在する．紫外線を浴びれば傷はただちに生じ，（64）光産物は6時間以内におおむね修復されるが, CPDは24時間後でも約50\%が未修復で残る。GGR の著しい低下は，若年の発がんにつながる.

この除去修復に欠陥を持つ色素性乾皮症（XP） 患者では, 生後 $2 \sim 3$ 回の日光曝露（日光浴）後に 顔には多数の小色素斑（シミ）が生じ, 脂漏性角 化症が $1-2$ 歳頃から顔や手背に出始める。つま り，XP患者は除去修復が正しく実行されないと， 光老化症状が早期に発症することを示している.

（2）日焼け(サンバーンとサンタン)とシミ・しわ “日焼け”は，太陽光を浴びた皮膚が赤くなる紅 斑反応 (サンバーン) と, 数日後から始まる褐色 の色素沈着（サンタン）の両現象を指している. サンバーンはまた遺伝子の傷が引き金となってお り，修復されないで残る傷の量が多いほどサンバ ーンはより強くなると考えられる。この考えを支 持するエビデンスとして，(1)XP患者皮膚では少量 の紫外線で強いサンバーンが生じる，(2)同じ紫外 線を浴びても色白で赤くなりやすい人は, 黒くて 赤くなりにくい人に比べ3〜 5倍ほど多くの傷が DNAに生じるため, より多くの傷が未修復で残る, (3)DNAの傷を効率良く修理するとサンバーンが起 きにくい，を挙げることができる，最近，我々は

図4 皮膚の老化度評価

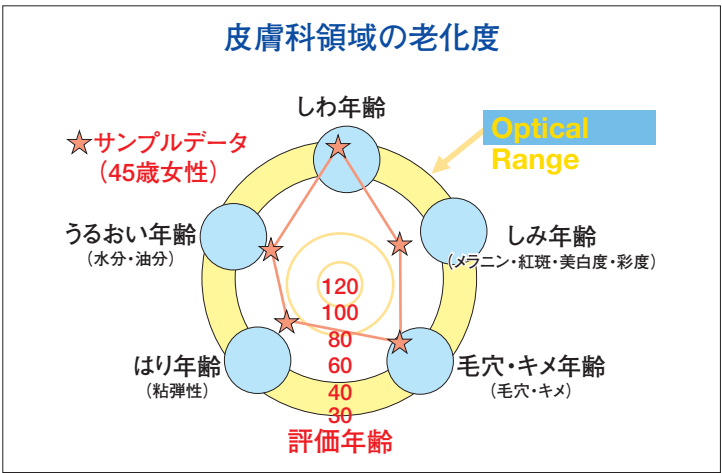

患者の肌年齢（しわ, シミ, 毛穴, キメ, うるおい, はり) をCCDカメ ラのモノクロ画像や, SKICON-200やCutometer MPA580を用いて計 測・評価する. 平均值 (中央值の上下 $25 \%$ ) とし, その外に分布し，老 化に向かっている患者に対しアンチエイジングの大切さを説明し, 治療 を実施する。 
紫外線BによるDNA損傷に引き続き, PPA-R $\gamma$ の 発現低下が起き, そのためCOX-2発現が高まり, PGE2量が増加し, サンバーンにつながるとの考 えを提示している。従って, PPAR $\gamma$ の発現を高 めれば化学伝達物質やサイトカインの生成が抑え られ，抗光老化につながるといえる.

メラニンは，太陽紫外線が表皮の角化細胞をは じめ，真皮が細胞に到達する量を軽減させる．表 皮角化細胞のDNA損傷量を3〜 5分の1に抑える (図3).

紫外線が表皮角化細胞を刺激し，bFGF， $a$ $\mathrm{MSH}$ やンドセリン 1 などのサイトカインを合成 放出する。これらの物質はパラクライン様式によ り表皮色素細胞に働き，それぞれの受容体を介し て, 細胞内にシグナルを送る。 $a$-MSHはサイク リックAMPを介してチロシナーゼのプロモーター であるMITFを活性化し，チロシナーゼのmRNA を増加させ, 蛋白量を増加し, 活性を立進させて メラニン合成を促進し，さらにメラニン合成に関 連するその他の遺伝子を活性化する.エンドセリ ン 1 は細胞内のCaイオンを動員させ, 細胞内の情 報伝達系を介して遺伝子の転写活性を上げ, メラ ニン合成を立進させる。なお， $a-\mathrm{MSH} \mathrm{ACTH}$ はその前駆物質POMCから作られるが，角化細胞 のPOMCのmRNA発現は紫外線照射で立進する。

急性反応を繰り返すことにより，顔や手背など 常に太陽光線に曝されている皮虐の角化細胞に遺 伝子に変異が生じ, SCFが過剩に生成分泌され, また色素細胞の遺伝子にも変異が生じるため, solar lentiginesなど光老化症状が生じる.

光老化皮膚の真皮では線維成分とそのあいだを 埋めるグリコサミノグリカン（酸性ムコ多糖）に 著しい量的，質的変化がみられる。特に，真皮乳 頭層ではactinic elastosis（光線性弾性線維変性） とよばれる変性弾性線維がみられる。Actinic elastosisの発症機序として, エラスチンの増加が 考えられる.さらに, UVBは角化細胞を刺激し, サイトカイン（IL-1a，IL-6）を介して真皮線維芽 細胞を刺激し, MMP-1の発現を高め, シワ形成を 促すと考えられている。一方, UVAは ${ }^{1} \mathrm{O}_{2}$ を介し, 線維芽細胞に働き，コラーゲン分子 I, III を分解 するMMP-1 (matrix metalloproteinase-1) と
MMP-2, さらにはコラーゲン IV と VII を分解する MMP-3のmRNAレベルを高め, 線維を切断し老化 症状の発症に関与するとの考えられている。

\section{老化度・光老化度の評価法}

小児期や思春期の若者の皮膚には老化症状は見 られない.しかし, 早老症・光早老症の臨床経験, 疫学調査や動物実験の観察から, また理論的にも 目に見える症状はなくても分子・細胞レベルで は，加齢により，また紫外線により遺伝子の変異 や細胞構成成分の変化がゆるやかに進行している と考えられる。これらの肉眼では認識できない分 子レベルの変化，および目に見える変化を老化 度・光老化度として計測できれば，アンチエイジ ングに役立つ。

すでに，老化度に関しては筋年齢，血管年齢， 神経年齢，ホルモン年齢と骨年齢が，老化危険因 子に関しては免疫機能, 酸化ストレス, 心身スト レス，生活習慣と代謝機能が評価対象とされてい る.皮膚の老化度評価については，いまだ一般的 な方法は確立されていない。そこで筆者は，比較 的簡便にしかも信頼性のある皮膚老化度計測対象 として以下の 8 項目を提案したい (図4).

1. シミ：顔面の直径 $2 \mathrm{~mm}$ 以上の色素斑の総面積を 年齢階級別に平均值を求め, それを元に点数評 価する。現在までの患者 387 人のシミの世代別 平均面積を示す (図5)。(ロボスキン)

2. シワ : 顔面の深さ $0.1 \mathrm{~mm}$ 以上, 長さ $3 \mathrm{~mm}$ 以上の 陥凹した皮膚をシワと定義し，年齢階級別に平 均值をもとめる. それを基に点数化し評価する。 (レプリカ法とロボスキン)

3. 皮膚の弾力性：皮膚に一定の陰圧を加えた後の 戻りを年齢階級別に点数評価. (Cutometer)

4. 皮膚のみずみずしさの評価：角質層の水分量を 物理的に計測する．年齢階級別に点数で評価す る. (Corneometer, SKICON)

5. 毛孔の状態：直径 $0.3 \mathrm{~mm}$ 以上の毛孔数を年齢階 級別に点数で評価する.

6. 皮膚の抗酸化度 : 角層のVit C, Eの定量を年齢 階級別に採点評価.（テープストリッピング）

7. 角層細胞：大きさ，数を年齢階級別に評価（テ ープストリッピング) 
8. 角層の酵素活性（剥がれやすさ）：酵素蛋白質 を抗体染色し年齢階級別に評価.（テープスト リッピング）

\section{光老化の予防と治療}

皮膚の老化，特に光老化は典型的生活習慣病で あり, 光加齢は生後はじめて日光を浴びる時から すでに始まっている。そのため皮膚のアンチエイ ジングは幼児期より始めるのが理想的である。幼 児期からの日焼け対策により顔や，手背などの光 老化症状を著しく遅らせることができる。つまり， 皮膚のアンチエイジングは可能といえる。近年の 進歩した科学手法を用いた研究から, 光老化は太 陽紫外線による遺伝子DNAの損傷の修復異常によ り発症することが明らかにされている．さらに， 紫外線曝露により細胞内外に生じる活性酸素やフ リーラジカルが光老化を誘発することも明らかに されている。したがって, 予防は第一に無駄な日 焼けを避けること，第二に活性酸素を早く消去す るか, または活性酸素が生じにくい皮膚の環境作 りである。また，DNA損傷をすみやかに修復させ る物質の塗布も有効と考えられる。

現時点で光老化（シミ，シワ）に対する最も有 効な予防法は, サンスクリーン剂の使用である。 強い日焼けを避けるため, sun protection factor （SPF）が50の製品を使用すれば，少し薄めに塗っ ても日焼けしにくい. 加えて，紫外線Aに対する サンスクリーン剤の選択が重要である。紫外線 A

図5世代別シミの平均值

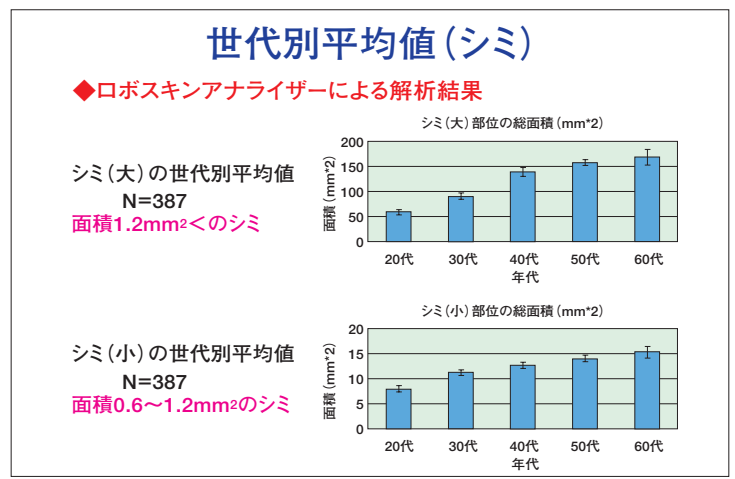

患者387人の世代別シミの平均面積を示す. 40 歳頃から急にシミが増加 する.
は活性酸素を介して光老化を誘発するからであ る。従って，単に紫外線を遮断するだけでなく， 生じる活性酸素を消去するため，ビタミンCなど の抗酸化剤を含有するサンスクリーン剤が有効で ある。

治療としては, シミに対しては過剩なメラニン 生成を抑えるため，酵素チロシナーゼの活性を阻 止するか，あるいは酵素を破壊する作用物質を美 白剤として使用する（アルブチン，コウジ酸，八 イドロキノン，リノール酸など)。次いで，メラ ニン生成を抑えるサプリメントや薬を服用する (L-システイン, ビタミンC, ビタミン $\mathrm{E}$, トラン サシン, CoQ10, グリチロンなど). 食物としては, これらサプリメントを多く含むもの，L-システイ ンであれば, 肧芽, 柿や蜂蜜, ビタミンCであれ ばプルーンやカシスなどのベリー類, オレンジな ど相橘類，CoQ10ならば鰞などである．抗酸化物 質はシミの原因にもなると考えられるPOMCの mRNA発現を抑制できるので，チロシナーゼの活 性を抑制する作用と合わせ, 美白効果が期待でき る.

深いシワの予防は紫外線対策 $(\mathrm{UVA}+\mathrm{B})$ であ る、レチノイン酸がシワの治療に有効なのは, 紫 外線により生成された活性酸素を介したシグナル 伝達系を途中で阻止し，コラゲナーゼのmRNA発 現上昇を抑制するからである。詳しい作用機序と してはMAP kinaseの活性化で生じるc-junの生成 を抑えるためといわれている。

図6 CoQ10によるUVA誘発コラゲナーゼmRNA の発現の抑制

\section{CoQ10はUVAによるコラゲナーゼの mRNA発現上昇を抑制する}

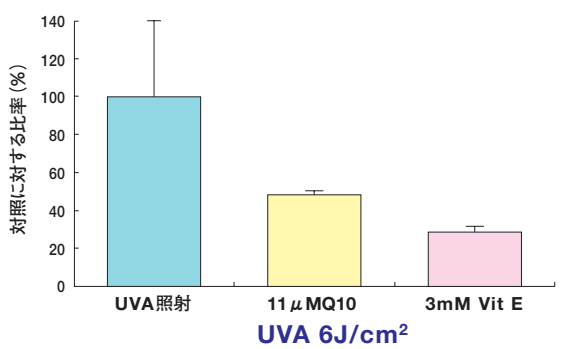

培養ヒト線維芽細胞をCoQ10 $11 \mathrm{mg} / \mathrm{ml}$ 添加条件で培養し他条件でUVA $6 \mathrm{~J} / \mathrm{cm} 2$ 照射した. 細胞のコラゲナーゼmRNAの発現が約 $50 \%$ 抑制され た. (Hoppe U, et al, Bio Factors, 1999) 
CoQ10は細胞に不可欠のエネルギーATPを作り 出すための補酵素として注目されているが，同時 に強力な抗酸化作用をもっている．また，CoQ10 は経年的に減少する．in vitroではあるが，CoQ10 は, 真皮線維芽細胞の紫外線Aによるコラゲナー ゼのmRNA発現上昇を抑制する（図6）。さらに $\mathrm{HaCaT}$ 細胞や培養正常ヒト角化細胞の紫外線 $\mathrm{A}$ よるDNA損傷（単鎖切断）を抑制することから， CoQ10が皮膚細胞でも抗酸化機能を発揮している と考えられる。したがって，CoQ10の経皮的塗布， あるいは経口的摂取による皮膚酸化の防止，つま りアンチエイジングが可能と考えられる.

CoQ10は脂溶性ではあるが，分子量が約 800 と大 きいため，経皮吸収はよくない。しかし，0.3\%の CoQ10エタノール液が豚皮膚を約 $20 \%$ 透過し，表 皮有棘層に移行し，2\%は真皮に達することから， ヒト皮膚での透過，吸収が期待できる。ヒト皮膚 に0.3\%CoQ10クリームを7日間，毎日2回塗布する と, 少量紫外線 $\mathrm{A}$ による活性酸素の発生（微量発
光）を抑制でき，さらに眼瞼周辺のシワの深さが 6 ケ月間の塗布で有意に減少する.

抗酸化力のある物質として広く認知されている ポリフェノールはワイン，お茶のカテキンやベリ 一類に多く含まれている. 最近, カシス（クロフ サスグリ）が目の周辺に生じるクマの治療に有効 なことも証明されている。カシスにはポリフェノ ールとして 4 種のアントシアニンが含まれてお り，それらの強い抗酸化に加え，末梢皮膚血流量 を増し，皮膚温を高めるためと考えられている。 このように，各種植物由来ポリフェノールがそれ ぞれ特徴ある作用機序で健康や美容に役立つと考 えられる。

最後に, 光老化は乳幼児期から始まることから, 小児期からの皮膚のアンチエイジングが必要なこ とを理解し, 適切な紫外線対策を実行し, 若々し い皮膚で高齢化社会を健康に生きることの意義 を，我々皮膚科医から国民に働きかけることが大 切と考えられる。

文献

1）市橋正光：光老化；光線による皮膚障害. 最新皮膚科学大系，第16巻「動物性皮膚症 環境因子によ る皮膚障害」，中山書店，東京，2003

2）船坂陽子：光老化を光で治す。アンチ・エイジング医学 2: 171-175, 20

3）市橋正光：美容とアンチエイジング.FOODStyle21 9 （Vol. 9）:31-39, 2005

4) Ando H, Watabe H, Valencia JC, Yasumoto K, Furumura M, Funasaka Y, Oka, Ichihashi M, Hearing VJ: Fatty acids regulate pigmentation via preteasomal degradation of tyrosinase. J Biol Chem 279 : 15427 15433, 2004

5) Maeda K, Hatao M: Involvement of photooxidation of melanogenic orecursors in prolonged pigmentation induced by ultraviolet A. J Invest Dermatol $122: 503-509,2004$

6) $\mathrm{Xu} \mathrm{Y,} \mathrm{Fisher} \mathrm{GJ:} \mathrm{Ultraviolet} \mathrm{(UV)} \mathrm{light} \mathrm{irradiation} \mathrm{induced} \mathrm{signal} \mathrm{transduction} \mathrm{in} \mathrm{skin} \mathrm{photoaging.} \mathrm{J}$ Dermatol Sci Suppl 1: 1-9, 2005

7) Hoppe U, Bergemann J, Diembeck W, Ennen J, Gohla S, Harris I, Jacob J, Kielholz J, Mei W, Pollet D, Schachtschabel D, Sauermann G, Schreiner V, Stab F, Steckel F : Coenzyme Q10, a cutaneous antioxidant and energizer. Bio Factors $9: 371-378,1999$.

8）松本均，伊藤恭子，米倉久美子，市橋正光：カシスポリフェノール経口摂取のくまに対する改善効果. 皮膚の科学 $4: 492-497,2005$. 